\title{
Expression of endo- I, 4-beta-xylanase from Trichoderma reesei in Pichia pastoris and functional characterization of the produced enzyme
}

\author{
Jun $\mathrm{He}^{1,2}$, Bing Yu¹,2, Keying Zhang1,2, Xuemei Ding ${ }^{1,2}$ and Daiwen Chen*1,2
}

Address: ${ }^{1}$ Institute of Animal Nutrition, Sichuan Agricultural University, Ya'an, Sichuan 625014, PR China and ${ }^{2}$ Key Laborotary of Animal DiseaseResistance Nutrition, Ministry of Education, Beijing, PR China

Email: Jun He - hejun8067@163.com; Bing Yu - ybingtian@yahoo.com.cn; Keying Zhang - zkeying@yahoo.com; Xuemei Ding - dingxuemei0306@163.com; Daiwen Chen*-daiwenc@yahoo.com

* Corresponding author

Published: 16 June 2009

BMC Biotechnology 2009, 9:56 doi:10.1 186/1472-6750-9-56
Received: 17 December 2008

Accepted: 16 June 2009

This article is available from: http://www.biomedcentral.com/l472-6750/9/56

(C) 2009 He et al; licensee BioMed Central Ltd.

This is an Open Access article distributed under the terms of the Creative Commons Attribution License (http://creativecommons.org/licenses/by/2.0), which permits unrestricted use, distribution, and reproduction in any medium, provided the original work is properly cited.

\begin{abstract}
Background: In recent years, xylanases have attracted considerable research interest because of their potential in various industrial applications. The yeast Pichia pastoris can neither utilize nor degrade xylan, but it possesses many attributes that render it an attractive host for the expression and production of industrial enzymes.

Results: The Xyn2 gene, which encodes the main Trichoderma reesei Rut C-30 endo- $\beta-I, 4-$ xylanase was cloned into the PPICZ $\alpha A$ vector and expressed in Pichia pastoris. The selected $P$. pastoris strains produced as $4,350 \mathrm{nkat} / \mathrm{ml} \beta$-xylanase under the control of the methanol inducible alcohol oxidase I (AOXI) promoter. The secreted recombinant Xyn 2 was estimated by SDS-PAGE to be $21 \mathrm{kDa}$. The activity of the recombinant $\mathrm{Xyn} 2$ was highest at $60^{\circ} \mathrm{C}$ and it was active over a broad range of $\mathrm{pH}(3.0-8.0)$ with maximal activity at $\mathrm{pH}$ 6.0. The enzyme was quite stable at $50^{\circ} \mathrm{C}$ and retained more than $94 \%$ of its activity after 30 mins incubation at this temperature. Using Birchwood xylan, the determined apparent $K_{\mathrm{m}}$ and $\mathrm{k}_{\text {cat }}$ values were $2.1 \mathrm{mg} / \mathrm{ml}$ and $219.2 \mathrm{~s}^{-1}$, respectively. The enzyme was highly specific towards xylan and analysis of xylan hydrolysis products confirmed as expected that the enzyme functions as endo-xylanase with xylotriose as the main hydrolysis products. The produced xylanase was practically free of cellulolytic activity.

Conclusion: The $P$. pastoris expression system allows a high level expression of xylanases. Xylanase was the main protein species in the culture supernatant, and the functional tests indicated that even the non-purified enzyme shows highly specific xylanase activity that is free of cellulolytic side acitivities. Therefore, $P$ pastoris is a very useful expression system when the goal is highly specific and large scale production of glycosyl hydrolases.
\end{abstract}

\section{Background}

Xylans are major hemicellulose component of plant cell wall, usually accounting for $20 \%-30 \%$ of their total dry mass. As they are the second most abundant natural polysaccharide after cellulose, complete degradation of them could generate various forms of cellulosic biomass and allow utilization of such low-cost raw materials for industrial applications [1]. Xylans have a relatively com- 
plex structure based on a non-branched $\beta$-1,4-glycosidically linked xylose backbone. Depending on the origin, the backbone structure is substituted to various degrees with acetyl, L-arabinofuranosyl, glucuronyl and 4-Omethylglucuronyl groups [2]. Complete degradation of xylans requires the synergistic action of several enzymes of which EC3.2.1.8-endo-beta-1, 4-xylanases are the crucial enzymes for depolymerization [3]. In recent years, xylanses have attracted considerable research interest because of their potential industrial application, such as in biobleaching, paper making and in the food and animal feed industries [4-6]. Various microorganisms, such as bacteria, yeasts, and filamentous fungi were found to naturally secreted xylanases.

The Trichoderma species has long been shown to secrete large amounts of efficient xylan-degrading enzymes, which render it an attractive microorganism for industrial enzyme production. The two major endo-xylanases secreted by this fungus are Xyn 1 and Xyn2. Xyn1 has an acidic pI (5.5), possesses a smaller, tighter groove than Xyn2, and a lower pH optimum [7]. Xyn2 has a basic pI (9.0) and a wider $\mathrm{pH}$ range. Both Xyn1 and Xyn2 produce similar hydrolysis end products. However, Xyn2 represents more than $50 \%$ of the total xylanolytic activity of this fungus and tends to produce larger oligosaccharides [5]. Today, the recombinant production hosts are preferred [8-10]. The recombinant production in fungal hosts, such as Trichoderma reesei, is not without problems, since they produce many enzymes at the same time. Although expression of some major enzymes (e.g. cellulase) has been knocked out, they still produce other enzymes that in certain applications can be problem [11].

Thus, production systems, in which a minimal amount of interfering side activities are produced, is desired. Xylanases can be produced in secreted form from $E$. coli, however, the production level is very low. [9,12-15]. The yeast Pichia pastoris can neither utilize nor degrade xylan, but it possesses many attributes that render it an attractive host for the expression and production of xylanases. As a eukaryote, Pichia pastoris has many of the advantages of higher eukaryotic expression systems such as protein processing, protein folding, and posttranslational modification, while being as easy to manipulate as E. coli or Saccharomyces cerevisiae. It is faster, easier, and less expensive to use than baculovirus or mammalian expression systems, and generally gives higher expression levels. As a yeast, it shares the advantages of molecular and genetic manipulations with S. cerevisiae and has the added advantage of 10 to 100 fold higher heterologous protein expression levels $[16,17]$. These features make Pichia very useful as a protein expression system.
In this study, we describe the molecular cloning of the $T$. reesei Xyn 2 gene in $P$. pastoris. Expression of the Xyn 2 gene in $P$. pastoris was obtained with the aid of multicopy plasmids, using the strong $P$. pastoris promoter-terminator expression cassettes derived from the inducible alcohol oxidase 1 (AOX1) gene. In addition, the enzymatic properties of the recombinant xylanase were characterized.

\section{Results \\ Cloning of the $\mathbf{T}$. reesei $X \mathbf{y n} 2$ gene}

The mature Xyn2 gene was prepared from first-strand cDNA prepared from $T$. reese $i$ Rut C-30 by using sequencespecific PCR primers. Thus a fragment of $570 \mathrm{bp}$ of Xyn 2 gene was obtained and sequenced [GenBank: EU532196]. The calculated molecular mass $(21 \mathrm{kDa})$ is in good agreement with the molecular mass of native Xyn2 isolated from T. reesei [7]. The T. reesei Rut C-30 Xyn2 gene has the same nucleotide sequence with VTT-D-79125 [GenBank: S67287]. Both of them are 99\% identical to wild type QM6 [GenBank: $\underline{\text { U24191] }}$, differing only two base pair substitutions (nucleotide 43, 272). The two substitutions probably resulted from its mutagenesis steps used in the mutant selection program $[18,19]$.

\section{Expression of the recombinant Xyn2 in P. pastoris}

The two specific primers (Up1 and Down1) were designated to incorporate the restriction enzyme sites EcoRI and NotI respectively at their 5 ' ends, allowing the directional cloning of the Xyn2 gene into pPICZ $\alpha$ A expression vector. The target fragment was integrated into $P$. pastoris $\mathrm{X}-33$ strain. The transformants were selected on YPDS plate containing zeocin and the integration of Xyn2 gene into AOX1 location in the genome was further confirmed by PCR. The most desired integrant was chosen for smallscale induction. The size of recombinant xylanase, determined by SDS-PAGE (Figure 1A) was $21 \mathrm{kDa}$, similar to that of the native xylanase secreted by $T$. reesei. SDS-PAGE also showed that the xylanase was the major protein (over $95 \%$ of total protein as detected by densitometer) secreted by $P$. pastoris into culture medium. Therefore, the procedure for protein purification was not necessary.

For optimal production of Xyn2, the recombinant $P$. pastoris was cultured in $2 \mathrm{~L}$ bioreactor. Both the highest xylanase activity $(4,350 \mathrm{nkat} / \mathrm{ml})$ and protein concentration $(0.35 \mathrm{mg} / \mathrm{ml})$ in culture supernatant was recorded after 72 $\mathrm{h}$ induction (Figure 2). However, the highest cell dryweight $(66 \mathrm{~g} / \mathrm{L})$ was obtained at $90 \mathrm{~h}$. Both xylanase activity and cell dry-weight decreased slightly in the late induction period (after $96 \mathrm{~h}$ ).

\section{Zymogram}

When the culture medium (after induction) were subjected to native-PAGE, xylanolytic activity was detected using oat-spelt xylan as substrate; Immersion of the sub- 
(B)

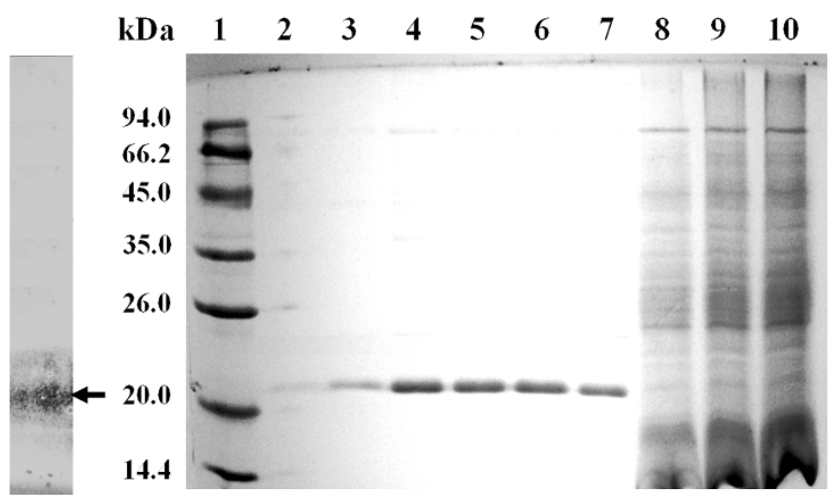

Figure I

SDS-PAGE and Zymogram analysis of expressed products. (A) SDS-PAGE analysis for expressed products. Lane I: protein marker; Lane 2-7: the culture supernatant containing recombinant xylanase from positive clones on day I, 2, 3, 4, 5, and 6; Lane 8-10: cell lysate from recombinant $P$. pastoris on day I, 3, and 5. (B) Zymogram analysis for xylanase activity. strate gel in ethanol resulted in precipitation of undegraded xylan, which enhanced contrast and revealed only one clear band against a black background (Figure 1B).

\section{Effect of $\mathrm{pH}$ and temperature on $\beta$-xylanase activity}

Enzymatic assay at different temperatures revealed that the recombinant Xyn2 has an optimal activity at $60^{\circ} \mathrm{C}$ (Figure 3A). Activity decreased rapidly with temperature, i.e., at $80^{\circ} \mathrm{C}$, activity of the recombinant protein represented only $30 \%$ of the optimum. Concerning the effect of the $\mathrm{pH}$, the enzyme showed an optimal activity at approximately pH 6.0 (Figure 3B). When the $\mathrm{pH}$ was below 3.0 and above 8.0 , only $30 \%-40 \%$ of the maximum activity was reached. Although the highest activity was measured at $60^{\circ} \mathrm{C}$, the enzyme is not stable at this temperature (only $40 \%$ activity retained after $30 \mathrm{~min}$ incubation). However, the recombinant Xyn 2 was stable at $50^{\circ} \mathrm{C}$, and the total activity retained more than $94 \%$ after 30 min incubating at this temperature (Fig 3C, D).

\section{Substrate specificity and kinetic parameters}

The hydrolytic activity of the recombinant enzyme on various substrates was determined (Table 1). The highest activity $(108 \%)$ was observed with the Birchwood xylan followed by the oat-spelt xylan (100\%). The enzyme exhibited low activities towards cellulosic substrates, such

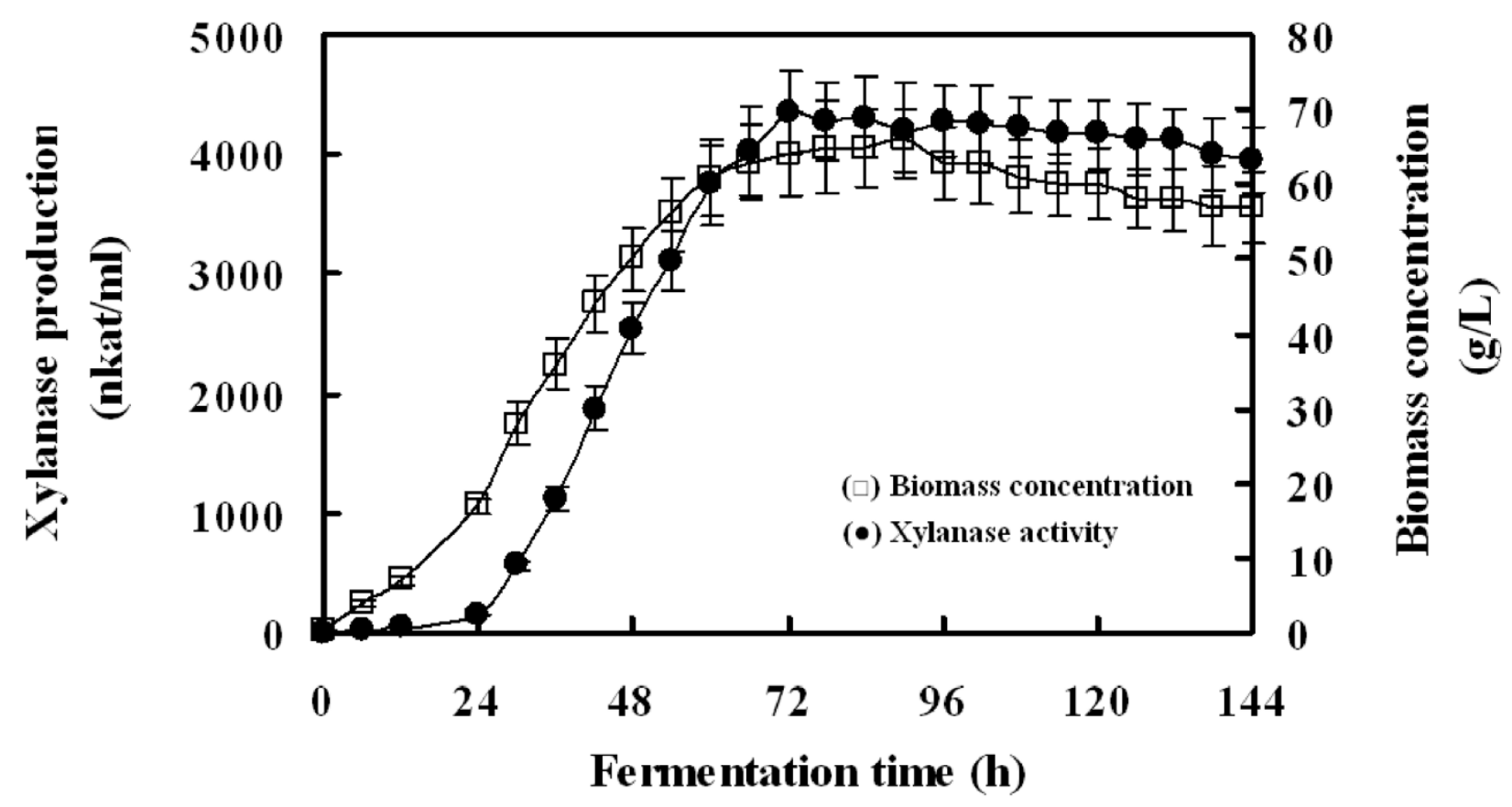

Figure 2

Time course of xylanase activity produced by recombinant $P$. pastoris. 

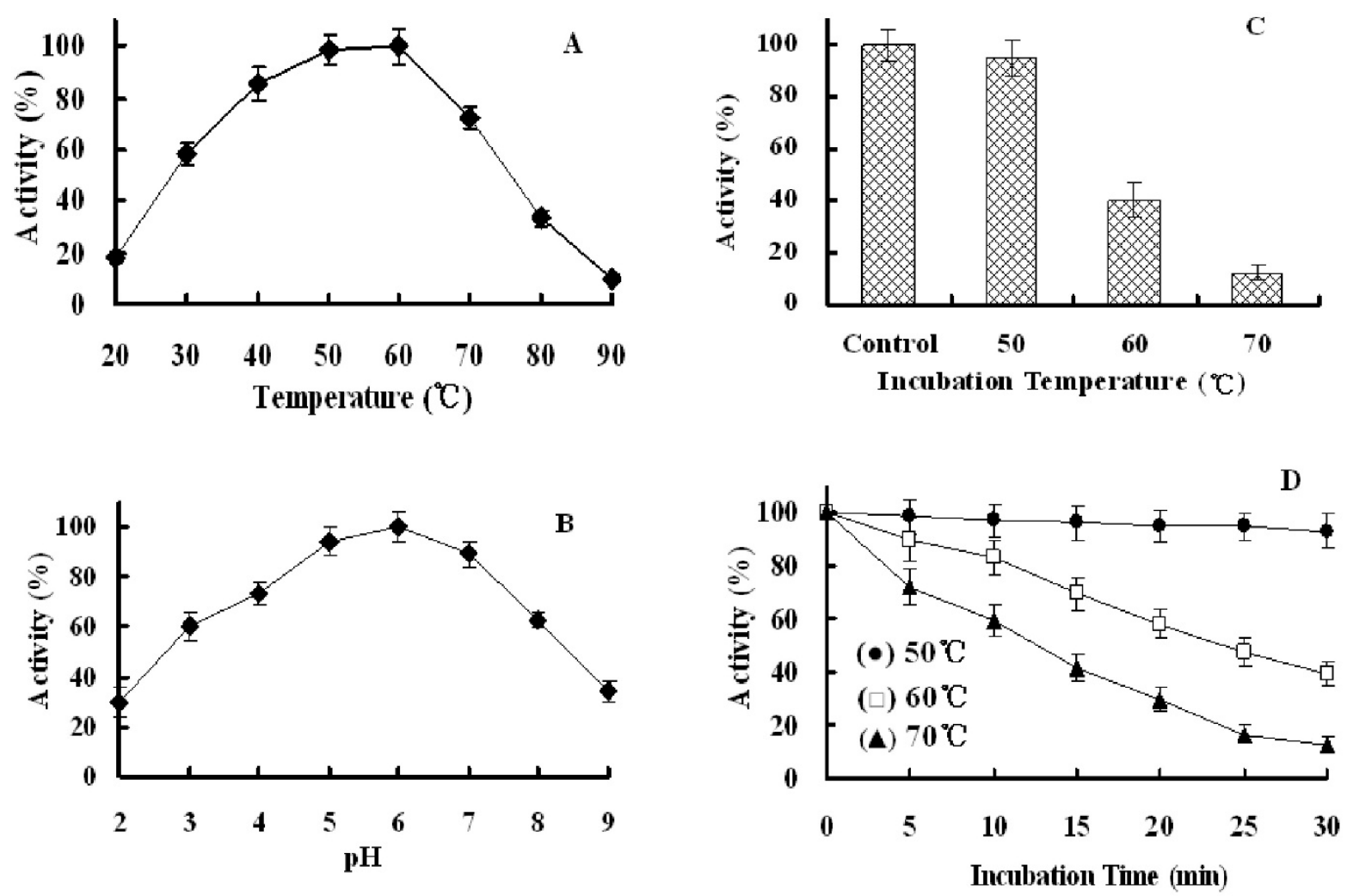

\section{Figure 3}

Characterization of the recombinant Xyn2. (A) Effect of temperature on the activity of Xyn2. (B) Effect of pH on the activity of Xyn2. (C) The temperature stability of Xyn2 was determined after preincubating the enzyme in the absence of the substrate for $30 \mathrm{~min}$ at 50,60 , and $70^{\circ} \mathrm{C}$. (D) The thermostability of Xyn2 at different temperatures was determined by preincubating the enzyme at these temperatures in the absence of substrate for 5, 10, 15, 20, 25, and 30 min before measuring its activity. The xylanase activity prior to the preincubations at different temperature was taken as $100 \%$.

Table I: Substrate specificity and kinetic constants for the recombinant xylanase (All the values are the means of three replications)

\begin{tabular}{lcccc}
\hline Substrate & Specific activity $(\mathbf{n k a t} / \mathbf{m l})$ & Relative activity' $(\%)$ & $\boldsymbol{K}_{\mathbf{m}}(\mathbf{m g} / \mathbf{m l})$ & $\mathbf{k}_{\text {cat }}(\mathbf{S}-\mathbf{l})$ \\
\hline Oat-spelt xylan & $4350 \pm 125$ & 100 & $1.8 \pm 0.02$ & $168.7 \pm 11.6$ \\
Birchwood xylan & $4687 \pm 187$ & 108 & $2.1 \pm 0.11$ & $205.7 \pm 19.5$ \\
Beechwood xylan & $3518 \pm 114$ & 83 & $1.4 \pm 0.13$ & $139.6 \pm 12.1$ \\
Gellan gum & $452 \pm 25$ & 11 & NA 2 & NA \\
Avicel & $78 \pm 8$ & 1.9 & NA & NA \\
CMC & $45 \pm 4$ & 1.4 & NA
\end{tabular}

IThe activity for oat-spelt xylan was defined as $100 \%$.

${ }^{2}$ Not available (The value is difficult to measure) 


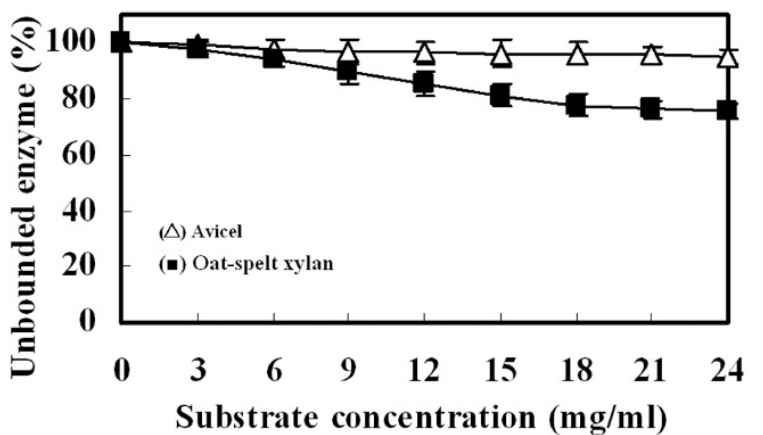

Figure 4

Effect of different concentrations of Avicel and oatspelt xylan on the binding ability of the recombinant Xyn2. Xylanase $(25 \mu \mathrm{g})$ was incubated with $\mathrm{I}-24 \mathrm{mg} / \mathrm{ml}$ Avicel or oat-spelt xylan in $50 \mathrm{mM}$ citrate phosphate $(\mathrm{pH} \mathrm{5.0)}$ at $4^{\circ} \mathrm{C}$.

as Gellan gum (11\%), Avicel (1.9\%) and CMC (1.4\%). The Michaelis-Menten constants were determined for the substrates. The $K_{\mathrm{m}}$ and $\mathrm{k}_{\mathrm{cat}}$ were $2.1 \mathrm{mg} / \mathrm{ml}$ and $205.7 \mathrm{~s}^{-1}$ for Birchwood xylan, and $1.8 \mathrm{mg} / \mathrm{ml}$ and $168.7 \mathrm{~s}^{-1}$ for oatspelt xylan, respectively.

\section{Polysaccharide-binding properties}

The polysaccharide-binding capacity of the recombinant Xyn 2 was determined by incubating the enzyme with Avicel or oat-spelt xylan. As shown in Figure 4, the recom-

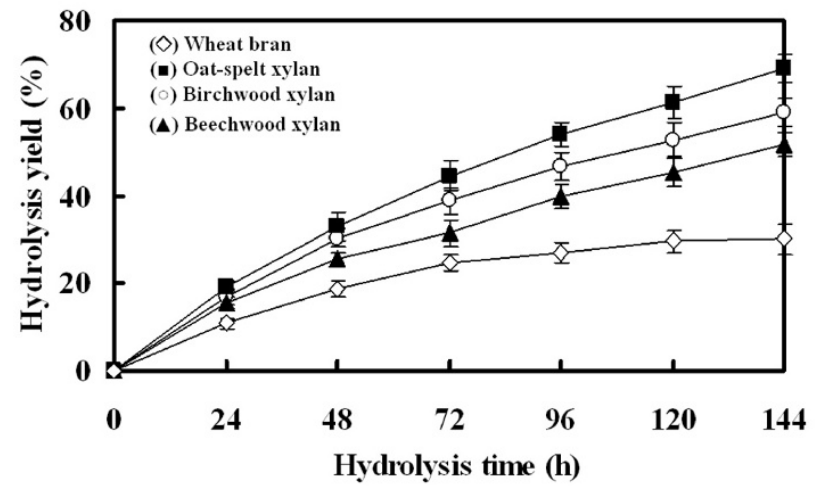

Figure 5

Hydrolysis capacity of the recombinant Xyn2. The hydrolysis yield of Oat-spelt xylan, Birchwood xylan, Beechwood xylan and Wheat bran using purified recombinant xylanase. Substrates $(2.5 \mathrm{~g})$ were incubated with $1000 \mathrm{nkat}$ of the enzyme in $50 \mathrm{ml} 50 \mathrm{mM}$ citrate buffer $(\mathrm{pH} 5.0)$ and the reaction was carried out at $50^{\circ} \mathrm{C}$ with shaking at $150 \mathrm{rpm}$. binant enzyme could not bind to Avicel, as about 95\% enzyme activity still remained in supernatant. In contrast, the enzyme did show its capacity to bind to xylan and $75 \%$ of the enzyme activity remained in the supernatant.

\section{Enzymatic hydrolysis of xylans}

The recombinant Xyn 2 has been used to hydrolyze substrates at $5 \%$ concentration. Yield of enzymatic hydrolysis was highest when Birchwood xylan was used as the substrate (Figure 5). The wheat bran hydrolysis was lowest (only 30\%), but the hydrolysis for both xylan and wheat bran linearly increased with the increasing of reaction time. The products of hydrolysis of oat-spelt xylan were analyased by TLC. The predominant hydrolysis end product of oat-spelt xylan was xylotriose (Figure 6). The xylotriose was produced within $5 \mathrm{~min}$ of the reaction period. As the reaction time increased, both the xylotriose and xylobiose concentration increased. These results confirmed that the recombinant Xyn2 was an endo-xylanase.

\section{Disccussion}

The filamentous fungus Trichoderma reesei (also known as Hypocrea jecorina) is one of the most efficient xylanase and cellulase producers. The highest total beta-xylanase activity obtained in shake flasks for hyperproducing mutant $T$. reesei Rut C-30 was up to $5400 \mathrm{nkat} / \mathrm{ml}[20]$. However, the $T$. reesei culture supernantant contains many enzymes involved in both hemicellulose and cellulose degrada-

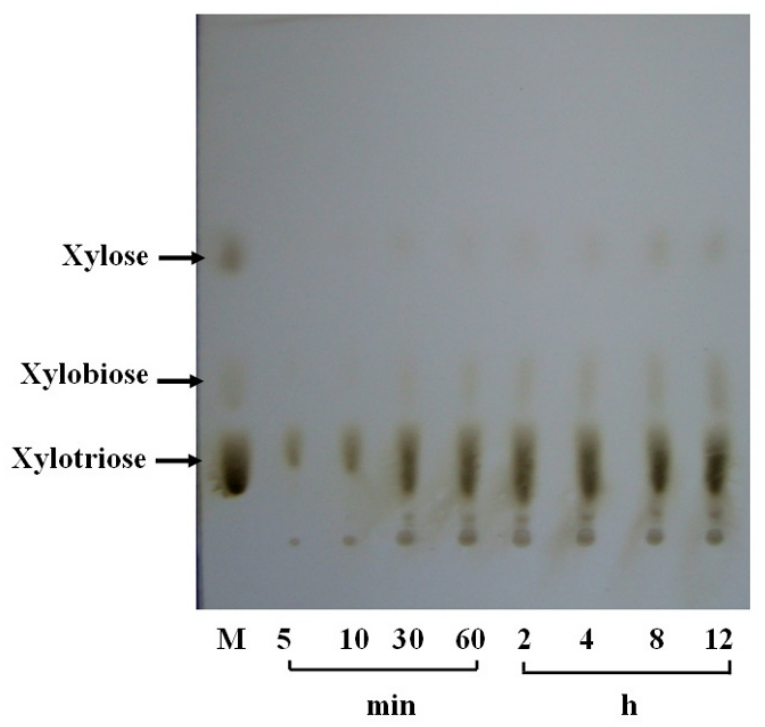

Figure 6

Analysis of the hydrolyzed products by the recombinant Xyn2. Oalt spelt xylan ( $40 \mathrm{mg}$ ) was incubated with 1000 nkat of the enzyme in $2 \mathrm{ml} 50 \mathrm{mM}$ citrate phosphate $(\mathrm{pH} 5.0)$ and the reaction was performed at $50^{\circ} \mathrm{C}$ for $12 \mathrm{~h}$ and then the hydrolyzates were analyzed by TLC. 
tion, and these side acitivities can be a problem for use in many applications[21]. To resolve this problem, many researchers utilized heterologous expression system to produce xylanase from recombinant microorganisms [810]. In this study, the xyn 2 gene from $T$. reesei Rut C-30 was successfully cloned and expressed in P. pastoris. For functional characterization, an unpurified enzyme was used and results indicated that even the non-purified enzyme shows highly specific xylanase activity. Therefore, $T$. reesei Xyn 2 produced in $P$. pastoris has an advantage of showing xylanase activity that is practically free of harmful side activities.

Currently, the heterologous expression has become one of the main tools for the production of industrial enzymes [22]. And P. pastoris was one of the favorite expression hosts because of many advantages as we described previously[16,17]. The Xyn 2 gene was inserted between a yeast promoter and transcription terminator on multicopy episomal plasmids to achieve high levels of gene expression [17]. For this purpose, we used the strong $P$. pastoris AOX1 promoter-terminator cassettes. In addition, the secretion signal sequence from $S$. cerevisiae $\alpha$ factor prepro peptide has been used to achieve a secretory expression. As a result, the recombinant xylanase was successfully secreted into the medium as a major protein with $95 \%$ purity and apparent molecular mass of $21 \mathrm{kDa}$. The highest total $\beta$ xylanase activity obtained in shake flasks for the most efficient recombinant $P$. pastoris strain was $4350 \mathrm{nkat} / \mathrm{ml}$, which is much higher than we obtained from E. coli (445 $\mathrm{nkat} / \mathrm{ml}$ ) [12]. The expression level is also higher than that of levels obtained from recombinant $S$. cerevisiae strain $(1,487 \mathrm{nkat} / \mathrm{ml})$ or other E. coli expression systems [1315]. Furthermore, the level may be higher than that of $T$. reesei Rut C-30 if one takes into account that the T. reesei culture supernatant contains other enzymes (i.e. xyn 1 and $\beta$-xylosidases) involved in xylan degradation $[8,20]$. As shown in table 2 there are many family 11 xylanases that have been expressed in $P$. pastoris [1,23-27]. However, most of them showed quite low expression levels, except in one study a higher level (11052 nkat/ml) was obtained for Aspergillus niger xylanase with the purity of the recom- binant protein being $86 \%$ [1]. As an unoptimized production level this is still missing from the efficiency of a recombinant $T$. reesei production system with published unoptimized production level of 32, $230 \mathrm{nkat} / \mathrm{ml}$ [28]. However, optimization is likely to further improve the production efficiency also in $P$. pastoris.

In comparison to Saccharomyces cerevisiae, P. pastoris may have another advantage in the glycosylation of secreted proteins because it may not hyperglycosylate. The mature Xyn2 produced by $T$. reesei has a molecular mass of 21 $\mathrm{kDa}$ as deduced from the amino acid sequence. The molecular mass of $P$. pastoris Xyn2 determined by SDSPAGE is almost the same. However, the molecular mass of the enzyme secreted by $S$. cerevisiae is $27 \mathrm{kDa}$ [8]. There is thus a $6-\mathrm{kDa}$ difference in the molecular mass of the Xyn2 secreted by $P$. pastoris and S. cerevisiae. This is caused by Nglycosylation [17], because S. cerevisiae tends to "hyperglycosylate" heterologous proteins. However, treatment of the S. cerevisiae Xyn2 with endoglycosidase F generated a new protein species with Molecular mass of $21 \mathrm{kDa}$, which corresponds to that of native Xyn 2 produced by $T$. reesei [8]. Though this large, glycosylated protein was efficently secreted into the culture medium, the lower expression level $(1,487 \mathrm{nkat} / \mathrm{ml})$ was not suitable for a large scale production.

Because the enzyme was the predominant protein (over $95 \%$ of total protein) in the culture medium, the procedure for protein purification was not necessary. When Birchwood xylan was used as the substrate, the recombinant Xyn 2 showed $K_{\mathrm{m}}$ and $\mathrm{k}_{\text {cat }}$ values of $2.1 \mathrm{mg} / \mathrm{ml}$ and $205.7 \mathrm{~S}^{-1}$, respectively. The $\mathrm{pH}$ and temperature optima of the recombinant Xyn2 compared well with the Xyn2 secreted by $S$. cerevisiae (Table 3 ). Both of them have a moderate thermostability and inactivated rapidly above $60^{\circ} \mathrm{C}[7,8]$. However, the P. pastoris Xyn2 retained at least $40 \%$ of its total activity after 30 mins incubation at $60^{\circ} \mathrm{C}$. The improved thermostability could be caused by amino acid mutation or glycosylation. In this study, the Xyn2 gene [GenBank: EU532196] was cloned from T. reesei Rut $\mathrm{C}-30$. However, the Xyn2 gene expressed in S. cerevisiae

Table 2: Expression levels of different recombinant family II xylanases in P. pastoris

\begin{tabular}{lccccc}
\hline Microorganisms & Host & Expression level' & Specific activity & Medium & Reference \\
\hline T. reesei & P. pastoris & $261 \mathrm{U} / \mathrm{ml}$ & $746 \mathrm{U} / \mathrm{mg}$ & BMMY & This study \\
B. licheniformis & P. pastoris & $163.5 \mathrm{U} / \mathrm{ml}$ & $122.9 \mathrm{U} / \mathrm{mg}$ & BMMY & {$[23]$} \\
A. niger & P. pastoris & $\mathrm{NA}$ & $175 \mathrm{U} / \mathrm{mg}$ & BMMY & {$[24]$} \\
A. niger & P. pastoris & $\mathrm{NA}$ & $\mathrm{NA}$ & $\mathrm{BMMY}$ & {$[25]$} \\
T. lanuginosus & P. pastoris & $360 \mathrm{U} / \mathrm{ml}$ & $\mathrm{NA}$ & BMMY & BMMY \\
A. sulphureus & P. pastoris & $120 \mathrm{U} / \mathrm{ml}$ & $773.1 \mathrm{U} / \mathrm{ml}$ & BMMY & {$[27]$} \\
A. niger & P. pastoris & $663 \mathrm{U} / \mathrm{ml}$ & {$[1]$}
\end{tabular}

II U $\approx 16.67$ nkat

${ }^{2}$ Not available 
Table 3: Comparison of the molecular characteristics between native $\mathrm{Xyn} 2$ and recombinant $\mathrm{Xyn} 2$

\begin{tabular}{|c|c|c|c|c|c|}
\hline \multirow[b]{2}{*}{ Property } & \multicolumn{4}{|c|}{ Value for Xyn2 from } & \multirow[b]{2}{*}{ Reference } \\
\hline & T. reesei & S. cerevisiae & P. pastoris & E. coli & \\
\hline Expression level (nkat/ml) & $5400^{1}$ & 1470 & 4350 & 445 & {$[7,8,12]$} \\
\hline Mol. mass $(\mathrm{kDa})$ & $20-21$ & 27 & 21 & 24 & {$[7,8,12]$} \\
\hline Optimum pH & 5 & 6 & 6 & 5 & {$[7,8,12]$} \\
\hline $\mathrm{pH}$ stability ${ }^{2}$ & $4.5-5.0$ & $4.0-7.0$ & $3.0-8.0$ & $3.5-7.5$ & {$[7,8,12]$} \\
\hline Optimum temp $\left({ }^{\circ} \mathrm{C}\right)^{3}$ & $50-55$ & 60 & 60 & 50 & {$[5,8,12]$} \\
\hline Temp. stability $\left(30 \mathrm{~min}, 60^{\circ} \mathrm{C}\right)$ & $\mathrm{NA}^{4}$ & NA & $40^{5}$ & $70^{5}$ & {$[7,8,12]$} \\
\hline
\end{tabular}

IT. reesei VTT-D-8627I (Rut C-30)

2 More than $60 \%$ of maximal activity retained.

${ }^{3}$ Optimum temperature was assayed at temperatures ranging from $20^{\circ} \mathrm{C}$ to $90^{\circ} \mathrm{C}$ for $10 \mathrm{~min}$.

${ }^{4} \mathrm{NA}$, not available.

$540 \%$ or $70 \%$ of total activity retained.

was cloned from QM6 $\alpha$ [GenBank: U24191]. There are two substitutions at nucleotides 43 and 272 of the Rut C30 Xyn2 DNA sequence, resulting in two amino acids (Try14/Glu91) in the protein being different from those in the protein (His14/Gly91) encoded by the QM6 $\alpha$ Xyn2 gene. In contrast, the E. coli Xyn2 seems to be more thermostable than $P$. pastoris and native Xyn2. Our laboratory has previously reported an E. coli expression of Xyn2 which presents a desired thermostability and retained at least $70 \%$ of its total activity after 30 mins incubation at $60^{\circ} \mathrm{C}$. The improved thermostability may result from the $\mathrm{N}$-terminal fusion peptide (51 amino acids). When the fusion peptide was deleted by enterokinase, the recombinant Xyn 2 retained only $50 \%$ of activity (unpublished results). Like with $T$. reesei Xyn2 expressed in S. cerevisiae, the $\mathrm{pH}$ optimum was the same for Xyn2 expressed in $P$. pastoris ( $\mathrm{pH}$ 6.0). The enzyme was active over the range of $\mathrm{pH}$ 3.0-8.0.

T. reesei Xyn2 is classified to family 11 xylanases and is characterized by its small molecular mass and alkaline isoelectric point [29]. The T. reesei Xyn2 have five binding sites (only three are found in Xyn1) for binding the xylopyranose rings in the vicinity of the catalytic site $[30,31]$. Only few family 11 xylanases are known to have substrate-binding domain, e.g. Thermomonospora fusca TfxA and Streptomyces lividans XylB [32,33]. TfxA binds to both cellulose and insoluble xylan, but the enzyme has activity against only xylan. In this study, the recombinant Xyn2 also exhibited a high activity for xylan, but a low activity for cellulosic substrates. These results were in good agreement with results from polysaccharide-binding analysis (Figure 4). When incubating the enzyme with Avicel, more than 95\% unbound enzyme was detected in the supernatant.

The hydrolytic capacity of the recombinant Xyn2 on pretreated substrates was also determined. More than $60 \%$ hydrolysis was obtained when oat spelt xylan (5\%) was used as the substrate, whereas less than 30\% hydrolysis was obtained with wheat bran. The decreased hydrolysis could be due to the fact that wheat bran contains more cellulosic compounds than xylan. In addition, the wheat bran is more difficult to dissolve. Usually, family 11 xylanases hydrolyze xylan to form oligosaccharides of different lengths [34]. In this study, Xyn2 expressed in P. pastoris hydrolyzed the oat-spelt xylan predominantly to xylotriose and in smaller amounts to xylobiose and xylose (Figure 6), which confirmed the endo-acting nature of the recombinant Xyn2. The xylooligosaccharides (i.e. xylotriose) has been found to be helpful for the maintenance of a healthy intestinal microflora [9]. But, the production of xylooligosaccharides is remaining a time consuming and expensive process. Therefore, the recombinant Xyn 2 may be used for the large-scale production of xylooligosaccharides.

\section{Conclusion}

In this study, the P. pastoris expression system designed for the high-production of Xyn2 allows large quantities of enzyme to be obtained in shake flasks. In addition, the recombinant Xyn 2 produced by $P$. pastoris are pure and completely free of any contaminating cellulases. The recombinant Xyn 2 exhibited a high specificity and hydrolysis capacity towards xylan. Coupled with its broad $\mathrm{pH}$ profile, all these features make the enzyme very useful for various industrial applications, such as in the animal nutrition and feed science. These results also suggested that the $P$. pastoris expression system is more suibtable for producing family 11 xylanases than other heterologous expression system. Future research in our laboratory will be focused on the development of a more effective vector for xylanase expression in $P$. pastoris and the co-expression of $\beta$-xylosidase or genes coding debranching enzymes will also be considered. 


\section{Methods \\ Strains and media}

$P$. pastoris X-33 was cultivated in YPD medium (1\% yeast extract, $2 \%$ peptone, $2 \%$ glucose). Trichoderma reesei Rut C-30 was cultivated in basal medium (BM) [0.3\% oat spelts xylan (Sigma), 0.4\% $\mathrm{KH}_{2} \mathrm{PO}_{4}, 1 \%\left(\mathrm{NH}_{4}\right)_{2} \mathrm{HPO}_{4}$, $1 \%$ peptone, $0.3 \%$ yeast extract] [35]. Both these organisms were cultured in $1 \mathrm{~L}$ flasks containing 100 to $200 \mathrm{ml}$ of medium at $30^{\circ} \mathrm{C}$ on a rotary shaker at $150 \mathrm{rpm}$.

Recombinant plasmids were constructed and amplified in Escherichia coli DH5 $\alpha$ cultivated at $37^{\circ} \mathrm{C}$ in Luria-Bertani liquid medium or Luria-Bertani agar. Ampicillin for selecting and propagating resistant bacteria was added to a final concentration of $100 \mu \mathrm{g} / \mathrm{ml}$.

\section{RNA isolation}

One liter of $T$. reesei Rut C-30 culture was incubated in oat spelts basal medium for $48 \mathrm{~h}$ at $30^{\circ} \mathrm{C}$. The fungal mycelia were harvest by centrifugation and frozen under liquid nitrogen. The frozen mycelia were ground into a fine powder with a sterile mortar and pestle, and suspended in a mixture of Trizol reagent (Takara D312), and total cellular RNA was isolated as described by the manual.

\section{Gene amplification and sequencing}

The first strand cDNA synthesis was carried out with 100 ng of total cellar RNA by using a two-step RT-PCR kit (Takara DRR019A) as specified by the supplier. The DNA fragment encoding the $T$. reesei Rut C-30 Xyn2 was isolated from a first-strand CDNA mix by PCR with the two oligonucleotides Up1 (5'-ATAGAATTCCAGACGATTCAGCCCGGCAC GGG-3') and Down1 (5'-TTAGCGGCCGCTTAGCT-GACGGTGATGGA AGCAGAGC-3') supplied with the Eco RI and Not I restriction sites respectively. These primers were based on the sequence of the $T$. reesei Xyn 2 gene, as published by La Grange et al [8]. The PCR reaction was performed in $25-\mu$ l reaction mixtures $(0.15 \mu \mathrm{M}$ each primer, $1 \mu \mathrm{l}$ of template DNA [about $10 \mathrm{ng}$ of first-strand cDNA], $12.5 \mu \mathrm{l}$ PCR premix [Boracker KT201-02]). Denaturation, annealing and polymerization were carried out for $1 \mathrm{~min}$ at $94^{\circ} \mathrm{C}, 1 \mathrm{~min}$ at $58^{\circ} \mathrm{C}$, and $1 \mathrm{~min}$ at $72^{\circ} \mathrm{C}$, respectively for 35 cycles. The PCR product was directly cloned to the pMD18T Simple Vector (TaKaRa D101A) and sequenced by Invitrogen (Shanghai, China) Co., Lid. The sequence was analyzed using the software package DNAman 5.0 (Lynnon Biosoft, USA) and the homology was analyzed in GenBank with the BLAST programs http://www.ncbi.nlm.nih.gov/BLAST.

\section{Construction and transformation of the recombinant plasmid}

An E. coli/P. pastoris shuttle vector, pPICZ $\alpha$ A (Invitrogen), was used to achieve secreted expression of xylanase. The mature Xyn2 gene obtained from PCR amplification was gel-purified and digested with EcoRI and NotI (Takara, Dalian) before cloning into pPICZ $\alpha$ A. After transformed into $E$. coli $\mathrm{DH} 5 \alpha$, recombinant plasmids were selected on Luria-Bertani agar containing $25 \mu \mathrm{g} / \mathrm{ml}$ zeocin. The selection was checked by restriction analysis and sequencing.

For $P$. pastoris integration, about $10 \mu \mathrm{g}$ of recombinant plasmid was linearized with sacI, and transformed in $P$. pastoris by electroporation methods as described by the manufacturer (Bio-Rad, USA). The transformants were selected at $28^{\circ} \mathrm{C}$ on the YPDS agar plates containing 100 $\mu \mathrm{g} / \mathrm{ml}$ zeocin. The integration of the Xyn 2 gene into the genome of $P$. pastoris was confirmed by PCR using 5 'AOX1 and 3'AOX1 primers.

\section{Expression of recombinant xylanase in $\mathbf{P}$. pastoris}

$P$. pastoris transformants were grown in $20 \mathrm{ml}$ of fresh buffered minimal glycerol complex medium, BMGY [1\% yeast extract, 2\% peptone, $100 \mathrm{mM}$ potassium phosphatate (pH 6.0), 1.34\% YNB, 0.0004\% biotin, and 1\% glycerol] at $30^{\circ} \mathrm{C}$ until an $\mathrm{OD}_{600}$ of $5 \sim 6$ was reached.

Then, the cell pellet was harvested and resuspended in $100 \mathrm{ml}$ buffered minimal methanol medium, BMMY [1\% yeast extract, $2 \%$ peptone, $100 \mathrm{mM}$ potassium phosphatate (pH 6.0), 1.34\% YNB, $0.0004 \%$ biotin, and 0.5\% methanol]. Sufficient supply of oxygen was assured by cultivation of the recombinant $P$. pastoris in $1 \mathrm{~L}$ flask (1:10 culture per flask volume ratio) at $250 \mathrm{rpm}$ agitation throughout induction period. Absolute methanol was added every $24 \mathrm{~h}$ to a final concentration of $1 \%$ to maintain induction. The culture supernatant was collected every day by centrifugation. The supernatant was stored at $-80^{\circ} \mathrm{C}$ before SDS-PAGE and analysis of its biochemical properties.

\section{Optimization of Xyn2 production in a $\mathbf{2} \mathbf{L}$ bioreactor}

A large scale production was performed in a $2 \mathrm{~L}$ bioreactor (B. Braun Sartorius Ltd.). Recombinant P. pastoris was grown in $200 \mathrm{ml} \mathrm{BMGY}$ medium. Temperature and $\mathrm{pH}$ were maintained at $30^{\circ} \mathrm{C}$ and 6.0 , respectively throughout growth phase for $16-18 \mathrm{~h}$. Agitation was kept within the range of 300-400 rpm. To induce enzyme production, cell pellets were resuspended in $800 \mathrm{ml}$ of BMMY medium containing 1\% methanol. The cultivation was maintained for 6 days by adding absolute methanol to a final concentration of $1 \%$ every day. Relative percentage of dissolved oxygen was maintained above $30 \%$ via adjusting agitation rate. Supernatants were collected every day and kept at $80^{\circ} \mathrm{C}$ before analysis. Cell pellets were washed, and dried at $80^{\circ} \mathrm{C}$ until constant weight was achieved.

\section{SDS-PAGE}

Sodium dodecyl sulfate-polyacrylamide gel electrophoresis (SDS-PAGE) on 15\% polyacrylamide was performed 
by the method of Laemmli [36]. The protein fractions were boiled for $3 \mathrm{~min}$ and applied to the gel. Proteins were visualized by Coomassie brilliant blue R 250 staining. The protein concentration was determined by the Bradford assay using bovine serum albumin as a standard [37].

\section{Zymogram analysis}

The recombinant protein exhibiting xylanolytic activity was detected by running it on native-PAGE (All denaturants were removed from SDS-PAGE) as described by Royer and Nakas [38]. The gel was washed twice with distilled water and overlaid on substrate gel $(1.5 \%$ oat spelt xylan, $1.5 \%$ agar in $50 \mathrm{mM}$ sodium phosphate buffer, $\mathrm{pH}$ 5.0). The gels were next smoothed to remove bubbles, wrapped in plastic, and incubated at $50^{\circ} \mathrm{C}$ for $20 \mathrm{~min}$. The gels were finally separated, and the substrate gels containing oat spelt xylan were immersed in 95\% ethanol for 45 min and were photographed while raised approximately 12 in. (ca. $30 \mathrm{~cm})$ above a black background.

\section{Enzyme activity assays}

Xylanase activity was assayed by the method described by Bailey et al. [39], with 1\% birchwood xylan xylan (Sigma) as the substrate at $50^{\circ} \mathrm{C}$ for $10 \mathrm{~min}$. Appropriate dilutions of the recombinant protein (culture supernatant) in 50 $\mathrm{mM}$ sodium citrate buffer ( $\mathrm{pH}$ 5.0) were used as the enzyme source. The amount of released sugar was determined by the dinitrosalicylic acid method described by Miller et al. [40]. One unit (nkat) of xylanase activity was defined as the quantity of enzyme that liberated reducing sugar at the rate of 1 nanomole per second. The temperature optimum was measured by performing the xylanase activity assay at temperatures ranging from $20^{\circ} \mathrm{C}$ to $90^{\circ} \mathrm{C}$. Thermostability was tested by heating enzyme samples for different times at various temperatures, and the activity was assayed at $50^{\circ} \mathrm{C}$ for $10 \mathrm{~min}$. Assays at different $\mathrm{pH}$ values were performed at the optimal temperature over a $\mathrm{pH}$ range of 3.0 to 8.0. The buffer used were $50 \mathrm{mM}$ citrate (pH 3.0), $50 \mathrm{mM}$ citrate phosphate (pH 4.0 to 7.0), and $50 \mathrm{mM}$ phosphate (pH 8.0), respectively.

\section{Substrate specificity and kinetic parameters}

Substrate specificity of the enzyme was determined using different cellulose and hemicellulose substrates. The reaction was carried out in $50 \mathrm{mM}$ citrate phosphate ( $\mathrm{pH}$ 5.0) containing $2.0 \mathrm{mg} / \mathrm{ml}$ of each substrate at $50^{\circ} \mathrm{C}$ for 10 min. For each assay, six different substrate concentrations were prepared in $50 \mathrm{mM}$ citrate phosphate ( $\mathrm{pH} 5.0$ ), and incubated with the purified enzyme at $50^{\circ} \mathrm{C}$ for $5 \mathrm{~min}$. The $K_{\mathrm{m}}$ and $\mathrm{k}_{\mathrm{cat}}$ values were calculated from the kinetics data as described by Jiang et al [9].

\section{Polysaccharide-binding properties}

The polysaccharide-binding capacity was determined by the method described by Tenkanen et al [41]. Purified
Xyn2 (30 $\mu \mathrm{g})$ was incubated with different concentrations of Avicel or oat-spelt xylan in $50 \mathrm{mM}$ citrate phosphate buffer ( $\mathrm{pH} 5.0$ ), at $4^{\circ} \mathrm{C}$ for $1 \mathrm{~h}$ with slow shaking. After centrifugation $(10000 \times \mathrm{g}$, $5 \mathrm{~min})$, the supernatant was collected and tested for its xylanase activity. Unbound enzyme was determined by measuring residual activity in the supernatant.

\section{Analysis of hydrolytic capacity and products}

The hydrolysis of xylan-based substrates was carried out in $100 \mathrm{ml}$ conical flask containing $50 \mathrm{ml}$ citrate buffer $(\mathrm{pH}$ $5.0,50 \mathrm{mM}), 2.5 \mathrm{~g}$ xylan or wheat bran, $5 \mathrm{mg}$ sodium azide and enzyme preparation (1000 nkat) as described by Adsul et al [42]. The hydrolysis was performed for 6 days at $50^{\circ} \mathrm{C}$, with a stirring rate of $150 \mathrm{rpm}$. The samples were analyzed for the reducing sugars after suitable time intervals. The hydrolyzed products of xylan was analyzed by the thin-layer chromatography (TLC) using silica gel plates 60 F 254 (E. Merck, Germany). Aliquots $(100 \mu \mathrm{l})$ of the samples were collected at 5, 10, $30 \mathrm{~min}, 1,2,4,8$, and $12 \mathrm{~h}$ of the incubation period and $1 \mu \mathrm{l}$ of the aliquot was spotted on the TCL plates. The plates were subsequently developed with two runs of acetonitrile-water $(85: 15, \mathrm{v} / \mathrm{v})$ followed by heating for a few minutes at $130^{\circ} \mathrm{C}$ in an oven after spraying the plates with a methanol-sulfuric acid mixture (95:5, v/v) [9]. A xylooligosaccharide mixture (Suntory Ltd, Japan) consisting of xylose, xylobiose, and xylotriose was used as the standard.

\section{Authors' contributions}

$\mathrm{HJ}$ and $\mathrm{YB}$ participated in the experimental design, carried out the molecular genetic and biochemical experiments, participated in data interpretation and helped draft the manuscript. ZK and DX conceived the study. CD directly supervised the project, participated in its experimental design and data interpretation and was responsible for writing the manuscript. All authors have read and approved the manuscript.

\section{Acknowledgements}

This work was granted by Feed Biotechnology Project of Sichuan Province of China with grant No.2007Z06-050 and Program for Changjiang Scholars and Innovative Research Team in University with grant. No. IRTO555-5, China Ministry of Education.

\section{References}

I. Ruanglek V, Sriprang R, Ratanaphan N, Tirawongsaroj P, Chantasigh $D$, Tanapongpipat S, Pootanakit K, Eurwilaichitr L: Cloning, expression, characterization, and high cell-density production of recombinant endo-I, 4- $\beta$-xylanase from Aspergillus niger in Pichia pastoris. Enzyme Microb Technol 2007, 4I:19-25.

2. Coughlan MP, Hazlewood GP: $\beta$-I,4-D-Xylan-degrading enzyme systems: biochemistry, molecular biology and applications. Biotechnol Appl Biochem 1993, 17:259-289.

3. Beg QK, Kapoor M, Mahajan L, Hoondal GS: Microbial xylanases and their industrial applications: a review. Appl Microbiol Biotechnol 200I, 56:326-338.

4. Buchert J, Ranua M, Kantelinen A, Viikari L: The role of two Trichoderma reesei xylanases in bleaching of pine kraft pulp. Appl Microbiol Biotechnol 1992, 37:825-839. 
5. Tenkanen M, Puls J, Potanen K: Two major xylanases of Trichoderma reesei. Enzyme Microb Technol 1992, 14:566-574.

6. Suchita N, Ramesh CK: Bleaching of wheat straw-rich soda pulp with xylanase from a thermoalkalophilic Streptomyces cyaneus SN32. Bioresource Technol 2006, 97:229I-2295.

7. Törrönen A, Mach RL, Messner R, Gonzalez R, Kalkkinen N, Harkki A, Kubicek CP: The two major xylanases from Trichodermo reesei : characterization of both enzymes and genes. Biotechnology 1992, 10:| 46|-| 465.

8. La Grange DC, Pretorius IS, Van Zyl WH: Expression of a Trichoderma reesei $\beta$-xylanase gene (XYN2) in Saccharomyces cerevisiae. Appl Environ Microbiol 1996, 62:1036-1044.

9. Jiang ZQ, Deng W, Zhu YP, Li LT, Sheng YJ, Hayashi K: The recombinant xylanase $B$ of Thermotoga maritima is highly xylan specific and produces exclusively xylobiose from xylans, a unique character for industrial applications. Journal of Molecular Catalysis B: Enzymatic 2004, 27:207-2 I3.

10. Saarelainen R, Paloheimo M, Fagerström R, Suominen PL, Nevalainen $\mathrm{KMH}$ : Cloning, sequencing and enhanced expression of the Trichoderma reesei endoxylanase II (pl9) gene. Mol Gen Genetics 1993, 241:497-503.

II. Paloheimo M, Mantyla A, Kallio J, Puranen T, Suominen P: Increased production of xylanase by expression of a truncated version of the xyn I IA gene from Nonomuraea flexuosa in Trichoderma reesei. Appl Environ Microbiol 1997, 73:3215-3224.

12. Jun H, Keying Z, Bing Y, Xuemei Ding, Daiwen Chen: Expression of a Trichoderma reesei $\beta$-xylanase gene in Escherichia coli and the activity of the enzyme on fiber-bond substrates. Protein Expr Purif 2009, 67: I-6.

13. Chenyan Z, Jiangyu B, Shanshan D, Jin W, Jie Z, Minchen W, Wu W: Cloning of a xylanase gene from Aspergillus usamii and its expression in Escherichia coli. Bioresource Technol 2008, 99:83I-838.

14. Junli H, Guixue W, Li X: Cloning, sequencing and expression of the xylanase gene from a Bacillus subtilis strain BIO in Escherichia coli. Bioresource Technol 2006, 97:802-808.

15. Yang Robert CA, Roger MACKenzie C, Bilous Doris, Seligy Verner L, Narang Saran A: Molecular cloning and expression of a xylanase gene from bacillus polymyxa in Escherichia coli. Appl Environ Microbiol I 988, 54:1023-1029.

16. Buckholz RG, Gleeson MAG: Yeast Systems for the Commercial Production of Heterologous Protein. Biotechnology 1991, 9:1067-1072.

17. Romanos MA, Scorer CA, Clare J): Foreign Gene Expression in Yeast: A Review. Yeast 1992, 8:423-488.

18. Bailey MJ, Nevalainen LMH: Induction, isolation and testing of stable Trichoderma reesei mutants with improved production of solubilizing cellulose. Enzyme Microb Technol I98I, 3:I53-I57.

19. Sheir-Neiss G, Montenecourt BS: Characterization of the secreted cellulases of Trichoderma reesei wild type and mutants during controlled fermentations. Appl Mcrobiol Biotechnol 1984, 20:46-53.

20. Bailey MJ, Buchert J, Viikari L: Effect of pH on production of xylanase by Trichoderma reesei on xylan- and cellulose-based media. Appl Microbiol Biotechnol 1993, 40:224-229.

21. Wong KKY, Saddler JN: Trichoderma xylanases, their properties and application. Critical Reviews in Biotechnology 1992, 12:4 |3-435.

22. Kirk O, Borchert TV, Fuglsang CC: Industrial enzyme application. Curr Opin Biotechnol 2002, I 3:345-35 I.

23. Liu MQ, Liu GF: Expression of recombinant Bacillus licheniformis xylanse A in Pichia pastoris and xylooligosaccharides released from xylans by it. Protein Expession and Purification 2008, 57:101-107.

24. Liu MQ, Weng XY, Sun JY: Expression of recombinant Aspergillus niger xylanse $A$ in Pichia pastoris and its action on xylan. Protein Expression and Purification 2006, 48:292-299.

25. Sun JY, Liu MQ, Xu YL, Xun ZR, Pan L, Cao H: Improvement of the thermostability and catalytic activity of a mesophilic family I I xylanase by $\mathrm{N}$-terminus replacement. Protein Expression and Purification 2005, 42:122-130.

26. Damaso MCT, Almeida MS, Kurtenbach E, Martins OB, Pereira N, Andrade CMMC, Albano RM: Optimized expression of a thermostable xylanase from Thermomyces lanuginosus in Pichia pastoris. Appl Environ Microbiol 2003, 69:6064-6072.

27. Cao Y, Qiao J, Li Y, Lu W: De novo synthesis, constitutive expression of Aspergillus sulphureus beta-xylanase gene in
Pichia pastoris and partical enzymic characterization. Appl Microbiol Biotechnol 2007, 76:579-585.

28. Paloheimo M, Mantyla A, Kallio J, Puranen T, Suominen P: Increased production of xylanase by expression of a truncated version of the xyn I IA gene from Nonomuraea flexuosa in Trichoderma reesei. Appl Environ Microbiol 2007, 73:32I5-3224.

29. Janis J, Rouvinen J, Leisola M, Turunen O, Vainiotalo P: Thermostability of endo-I, 4- $\beta$-xylanase II from Trichoderma reesei sudied by electrospary ionization Fourier-transform ion cyclotron resonance MS, hydrogen/deuterium-exchange reactions and dynamic light scattering. Biochem J 200I, 356:453-460

30. Jeffries TW: Biochemistry and genetics of microbial xylanases. Environ Biotechnol 1996, 7:337-342.

31. Davies G, Henrissat B: Structures and mechanisms of glycosylhydrolases. Structure 1995, 3:853-859.

32. Black GW, Hazlewood GP, Millwardsadler SJ, Laurie JI, Gilbert HJ: A modular xylanase containing a novel noncatalyutic xylanspecific binding domain. Biochem J 1995, 307:191-195.

33. Irwin D, Jung ED, Wilson DB: Characterization and sequence of a Thermomonospora fusca xylanase. Appl Environ Microbiol 1994, 60:763-770

34. Biely P: Microbial xylanolytic systems. Trends Biotechnol 1985 , 3:286-290.

35. Matsuo M, Yasui T: Purification and some properties of $\beta$-xylanase from Trichoderma viride. Agric Biol Chem 1984, 48: $1845-1852$.

36. Laemmli UK: Cleavage of structural proteins during the assembly of the head of bacteriophage T4. Nature (London) 1970, 227:680-685.

37. Bradford MM: A rapid sensitive method for the quantitation of microgram quantities of protein utilizing the principle of protein-dye binding. Anal Biochem 1976, 72:248-254.

38. Royer JC, Nakas JP: Simple, sensitive zymogram technique for detection of xylanase activity in polyacrylamide gels. Appl Environ Microbiol 1990, 56:1516-1517.

39. MJ Bailey, Biely P, Poutanen K: Interlaboratory testing of methods for assay of xylanase activity. J Biotechnol 1992, 23:257-270.

40. Miller GL, Blum R, Glennon WE, Burton AL: Measurement of carboxymethylcellulase activity. Anal Biochem 1960, 2:127-132.

4I. Tenkanen M, Buchert J, Uiikari L: Binding of hemicellulases on isolated polysaccharide substrates. Enzyme Microbe Technol 1995, 17:499-505.

42. Adsul MG, Bastawde KB, Varma AJ, Gokhale DV: Strain improvement of Penicillium janthinellum NCIMII7I for increased cellulase production. Bioresource Technol 2007, 98: |437-I473.
Publish with Bio Med Central and every scientist can read your work free of charge

"BioMed Central will be the most significant development for disseminating the results of biomedical research in our lifetime. "

Sir Paul Nurse, Cancer Research UK

Your research papers will be:

- available free of charge to the entire biomedical community

- peer reviewed and published immediately upon acceptance

- cited in PubMed and archived on PubMed Central

- yours - you keep the copyright
BioMedcentral 